\title{
Marine zooplanktonic diversity: a view from the South Atlantic
}

\section{Diversité du zooplancton marin : un regard sur l'Atlantique Sud}

\author{
Demetrio Boltovskoy ${ }^{\mathrm{a}, *}$, Nancy Correa ${ }^{\mathrm{b}}$, Andrés Boltovskoy ${ }^{\mathrm{c}}$ \\ a'Departamento de Ecología, Genética y Evolución, Facultad de Ciencias Exactas y Naturales, Universidad de Buenos Aires, 1428 Buenos Aires, \\ Argentina (Consejo Nacional de Investigaciones Cientificas y Técnicas, Museo Argentino de Ciencias Naturales "Bernardino Rivadavia") \\ ${ }^{\mathrm{b}}$ Servicio de Hidrografia Naval, Av. Montes de Oca 2124, 1271 Buenos Aires, Argentina \\ ${ }^{\mathrm{c}}$ Facultad de Ciencias Naturales y Museo, Universidad Nacional de La Plata, 1900 La Plata, Argentina (Consejo Nacional de Investigaciones
}

Cientificas y Técnicas)

\begin{abstract}
Approximately 7000 marine zooplanktonic species have been described so far for the World Ocean; in the South Atlantic the presence of $40 \%$ of these has been confirmed, and an additional $20-30 \%$ are expected to be recorded in the future. The overall number of described species is very low when compared with other communities, and yet it may not be too far from the final, complete inventory. Very ample geographic distributional ranges, compositional similarity between the major oceanic basins, and declining species description rates suggest that the undescribed fraction of marine zooplankton is nowhere as large as those suggested for the biosphere as a whole. It is anticipated that the highest proportions of new species will be among the groups associated with the sea-floor (meroplanktonic and benthopelagic forms). However, the fact that a high proportion of the marine zooplanktonic species has already been described does not imply that the corresponding taxonomic systems are adequate and that our understanding of this community is better than that of others where undiscovered species are still the overwhelming majority. For most marine zooplanktonic species we have extremely scarce biological and ecological information. Furthermore, the taxonomy of several quite speciose groups is in such a state of disarray that synonyms by far outnumber "good species".
\end{abstract}

(C) 2002 Ifremer/CNRS/IRD/Éditions scientifiques et médicales Elsevier SAS. All rights reserved.

\section{Résumé}

Près de 7000 espèces de zooplancton ont été décrites pour l'océan mondial. Près de $40 \%$ d'entre elles se retrouvent dans l'Atlantique Sud où l'on pourrait encore découvrir de 20 à $30 \%$ des espèces restantes. Ce nombre total est bas comparé à d'autres communautés alors même qu'il n'est pas si éloigné de l'inventaire final. Une distribution géographique large, une composition proche entre les deux bassins océaniques majeurs et le taux décroissant de découverte d'espèces nouvelles, tout ceci suggère que la fraction non décrite du zooplancton dans l'océan mondial est bien inférieure à ce qui reste à décrire pour la biosphère dans son ensemble. La plupart des espèces nouvelles devraient appartenir aux groupes associés aux fonds marins avec les formes méroplanctoniques et benthopélagiques. Bien qu'une bonne fraction des espèces ait été découverte, le système taxinomique étant peu adapté, la connaissance de cette communauté n'est pas meilleure que celle d'autres communautés où la fraction d'espèces décrites est pourtant bien plus faible. En effet, pour la plupart des espèces décrites, nous disposons de peu d'informations à propos de leur biologie et de leur écologie. De plus, la taxinomie de plusieurs groupes est tellement discutable que les synonymes dépassent largement le nombre de «bonnes» espèces.

(C) 2002 Ifremer/CNRS/IRD/Éditions scientifiques et médicales Elsevier SAS. Tous droits réservés.

Keywords: Zooplancton; Diversity; South Atlantic

Mots clés: Zooplancton; Diversité; Atlantique Sud

\footnotetext{
* Corresponding author.

E-mail address: demetrio@bg.fcen.uba.ar (D. Boltovskoy).
} 


\section{Introduction}

Although in its broad sense the concept of biodiversity goes far beyond the inventory of the species present in a given space and time envelope, assessment of the numbers of species is clearly a key component of most biodiversity -oriented surveys; accordingly, much of the recent literature on this issue focuses on the fact that a very large proportion of the plants and animals that inhabit our planet have not yet been described. While true for much of the terrestrial and freshwater flora and fauna, these generalizations do not seem to apply to the marine zooplankton. In this review we will attempt to show that marine zooplanktonic species are comparatively very few in number, and that a very large proportion of them has already been discovered, largely because their geographic ranges are very wide. This, however, does not preclude the fact that for several zooplanktonic groups classification systems are in a very serious state of disarray, and that distributional and ecologic data are very scarce for almost all planktonic organisms. Thus, our understanding of the biodiversity (in the broad sense) of the marine pelagial is not better than that of terrestrial or freshwater communities, but approaches toward improving this knowledge differ from those necessary for other plant and animal groups.

\section{Overall diversity of marine zooplankton and biogeographic zonations}

The overall total of marine zooplanktonic (chiefly holoplanktonic) species described to date is approximately 7000 (Boltovskoy et al., 1999; see Table 1). When compared with other communities, the number of marine planktonic species (including the phytoplankton, which according to Sournia et al., 1991, comprises ca. 4000 described species) is clearly at the bottom of the spectrum. Non-planktonic marine organisms have between 180000 and 200000 species (Zenkevitch, 1960; Briggs, 1996). Marine species in general, in turn, represent less than $15 \%$ of the known overall species diversity on earth, where some 1500000 terrestrial and freshwater species have been described so far (Briggs, 1996; Wilson, 1999).

This comparatively poor diversity is chiefly the result of the fact that distributional barriers for marine plankters are very few and very diffuse, which in turn results in comparatively few biogeographic divisions (Bé and Tolderlund, 1971; McGowan, 1974; Pierrot-Bults and Spoel, 1979; Hemleben et al., 1989; McGowan and Walker, 1993; Angel, 1996). For example, in the entire (epipelagic) Pacific Ocean, an area spanning over 180 million square kilometers, only eight distinct planktonic provinces are recognized; furthermore, six of these are made up to a considerable degree of species with amphitropical distributions (McGowan, 1974). Admittedly, zonations with more areas have also been proposed, but these are either not based on species ranges (e.g., Longhurst, 1998), or rely on subjective interpretations of the distribution of limited subsets of organisms (e.g., Beklemishev, 1969). Most comprehensive worldwide zooplanktonic biogeographic zonations recognize five (or four paired plus one) major non-coastal circumglobal zones: Polar (Arctic and Antarctic), Subpolar (Subarctic and Subantarctic), Transitional and Subtropical (Northern and Southern), and Equatorial or Tropical (e.g., Bé and Tolderlund, 1971; Backus, 1986; Hemleben et al., 1989; Boltovskoy, 1998). In contrast, land-based major biogeographic divisions usually include over 20-30 firstorder provinces (e.g., Bailey, 1996). Moreover, terrestrial and marine coastal biogeographic zonations are almost invariably based on taxonomic categories higher than those used for pelagic zonations, which further enhances the taxonomic homogeneity of marine zooplanktonic assemblages worldwide (Ekman, 1953; Pierrot-Bults and Spoel, 1979).

\section{South Atlantic inventories vs. World Ocean totals}

An estimate of the number of zooplanktonic species described worldwide that have also been recorded in the South Atlantic, along with a subjective assessment of the degree of coverage of each group in this basin, is given in Table 1. These figures indicate that for the taxa whose coverage in the South Atlantic is considered very good or good, the mean fraction of worldwide known species that have also been found in these waters is $70 \%$. For those labeled "regular" the fraction is $57 \%$, whereas for the poorly or very poorly covered in the South Atlantic it is $35 \%$. As expected, these numbers confirm that similarities between the worldwide and the regional inventory are strongly influenced by degree of coverage and sampling effort. In addition, these estimates seem to be also affected by the overall number of species comprising each group, lower percentages being generally associated with higher diversities (Table 1).

Based on the above considerations, we anticipate that for many holozooplanktonic groups percentages of the worldwide inventories present in the South Atlantic will eventually get closer to the figures presently exhibited by foraminifers and appendicularians (i.e., 70-80\%). This conclusion is supported by the remarkable cosmopolitanism of marine plankton in general, which contrasts strikingly with similar estimates for benthic animals. About $85 \%$ of the deep-sea World-Ocean fauna occur in one ocean only, while only $4 \%$ are common to all three oceans (Briggs, 1996). In contrast, for pelagic plankton circumglobal distribution patterns are more common than endemisms. For example, according to Spoel and Dadon (1999), of the 91 species and subspecific categories of Pteropoda present in the Atlantic, only $26 \%$ are restricted to this ocean. Over $90 \%$ of the planktonic foraminifers inhabit all three major oceans (Boltovskoy, 1981). Approximately $70 \%$ of the ca. 
Table 1

Estimated numbers of marine zooplanktonic species for the World Ocean and for the South Atlantic (modified from Boltovskoy, 1999a)

\begin{tabular}{|c|c|c|c|}
\hline Group & $\begin{array}{l}\text { Approximate number of species } \\
\text { in the World Ocean }\end{array}$ & $\begin{array}{l}\text { Approximate number of species } \\
\text { in the South Atlantic }\end{array}$ & $\begin{array}{l}\text { Knowledge of the group } \\
\text { in the South Atlantic }\end{array}$ \\
\hline Foraminifera & 49 & 39 & Very good \\
\hline Acantharia & 150 & $?$ & Very poor \\
\hline Radiolaria Polycystina & 350 & 160 & Poor \\
\hline Radiolaria Phaeodaria & 350 & 158 & Very poor \\
\hline Ciliophora & 150 & 58 & Very poor \\
\hline Tintinnida & 300 & 151 & Regular \\
\hline Hydromedusae & 650 & 185 & Regular \\
\hline Siphonophora & 190 & 98 & Regular \\
\hline Scyphozoa & 150 & 38 & Poor \\
\hline Ctenophora & 80 & 20 & Poor \\
\hline Nemertina & 97 & 11 & Very poor \\
\hline Polychaeta & 120 & 61 & Poor \\
\hline Heteropoda & 35 & 26 & Regular \\
\hline Pteropoda & 160 & 91 & Good \\
\hline Cephalopoda & 370 & 103 & Very poor \\
\hline Cladocera & 8 & 8 & Good \\
\hline Ostracoda & 169 & 120 & Regular \\
\hline Copepoda & 2000 & 505 & Poor \\
\hline Mysidacea & 700 & 96 & Very poor \\
\hline Amphipoda & 400 & 188 & Very poor \\
\hline Euphausiacea & 86 & 61 & Good \\
\hline Chaetognatha & 80 & 37 & Good \\
\hline Appendicularia & 64 & 43 & Good \\
\hline Pyrosomatida & 8 & 6 & - \\
\hline Doliolida & 17 & 11 & Regular \\
\hline Salpida & 45 & 29 & Very good \\
\hline Total & 6778 & 2500 & - \\
\hline
\end{tabular}

200 species of planktonic Amphipoda occurring in the Atlantic are also present in the other major oceans (Vinogradov, 1999). Of the 35 described species of Heteropoda only three (8\%) are restricted to a single oceanic basin, nine $(26 \%)$ have been recorded in two, and $23(66 \%)$ are present in all three major oceans (Richter and Seapy, 1999).

Exceptions to this pattern are centered on taxa with high percentages of neritic forms and/or benthopelagic representatives, both of which tend to have more restricted geographic ranges. For example, the fact that of the $>900$ known mysid species only $96(10 \%)$ have been found in the South Atlantic is largely due to the fact that these animals are closely associated with the sea floor (Murano, 1999 and pers. comm.) The benthic sessile stage of the Hydromedusae is responsible for their comparatively high endemism: South Atlantic materials have yielded less than $30 \%$ of the World Ocean fauna (Bouillon, 1999). Nevertheless, in terms of numbers of species, taxa rich in neritic and/or benthopelagic forms roughly comprise less than $25 \%$ of the total.

\section{Historical trends in species description rates}

The total number of described species is around 1.5 million, comprising some 1 million animals and ca. 500000 plants. However, most estimates agree that these numbers are but a fraction of actual biological diversity on Earth, where anywhere between 12 and 30 million species dwell (Briggs, 1996; Wilson, 1999). According to the Zoological
Record, between 1978 and 2000 ca. 360000 new animal species and subspecies have been proposed (including 22 new phyla), and the current rate is about 17000 new animal names per year. Thus, roughly $25 \%$ of all known animals have been described in the last 20 years, and approximately $1 \%$ is added yearly to the existing list of animal species.

However, this increment is obviously not distributed homogeneously over the entire animal spectrum. Inventories of the most conspicuous animals have increased little in the last decades, with many of the small-sized, "less appealing", and particularly the species-rich groups taking up most of the difference. A very general idea of the state of the various inventories can be gained from an overview of the historical trends in the rates of description of new species through time: it seems reasonable to assume that groups for which species description rates have declined steadily in the last decades are closer to the global total than those where description rates have increased toward the present or not subsided noticeably. Fig. 1 shows that half of the known species of the vertebrate animals (included in the graph) were described before 1835 , but for the invertebrates a similar percentage was reached only after 1852 . Close to $30 \%$ of the living species of marine mammals were described before 1800 , and by $192595 \%$ of the representatives presently known were published (Northridge, 1984). For the order Primates, also around 95\% of the living species were described before 1950 (Groves, 1993). On the other hand, for the invertebrate groups shown $50 \%$ of the species known in 2000 were described between 1852 and as late as 1960 


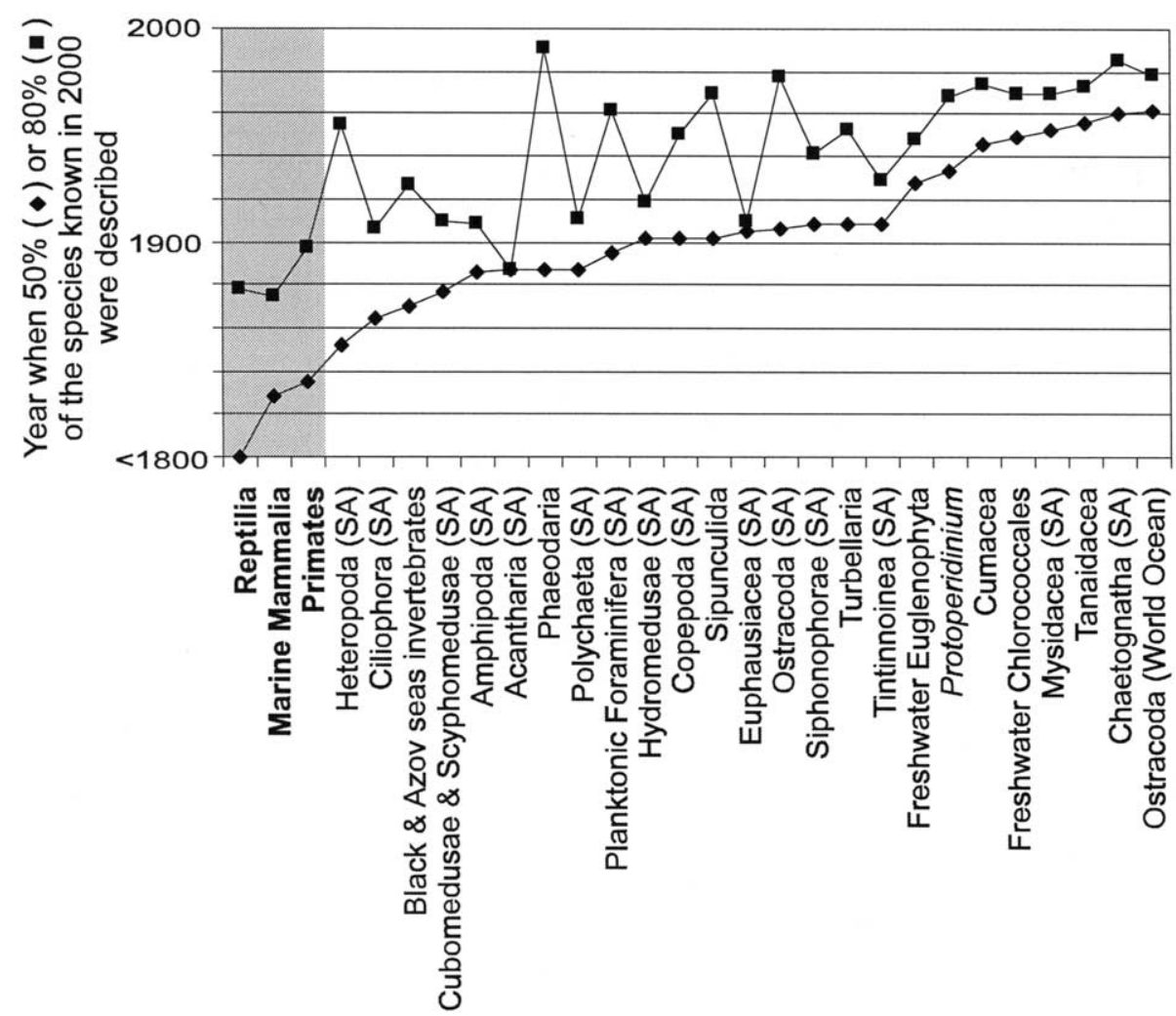

Fig. 1. Years when 50 and $80 \%$ of the species known in 2000 were described for several animal groups. Sources. Reptilia: Andreu et al. (1993, Fauna Ibérica); Marine Mammalia: Northridge (1984); Primates: Groves (1993); Heteropoda: Richter and Seapy (1999); Ciliophora: Petz (1999); Black \& Azov seas invertebrates: Mordukhai-Boltovskoi (Ed., 1969, 1972); Cubomedusae \& Scyphomedusae: Mianzan and Cornelius (1999); Acantharia: Bernstein et al. (1999); Phaeodaria: Kling and Boltovskoy (1999); Polychaeta: Fernández-Alamo and Thuesen (1999); planktonic Foraminifera: Kemle von Mücke and Hemleben (1999); Hydromedusae: Bouillon (1999); Copepoda: Bradford-Grieve et al. (1999); Sipunculida: Saiz Salinas (1993); Euphausiacea: Gibbons et al. (1999); Ostracoda: Angel (1999); Siphonophorae: Pugh (1999); Turbellaria: Noreña (1999); Tintinnoinea: Alder (1999); freshwater Euglenophyta: Starmach (1983); Protoperidinium: Balech and Boltovskoy (in press); Cumacea: Bacescu (1988); freshwater Chlorococcales: Komarek and Fott (1983); Mysidacea: Murano (1999); Tanaidacea: Sieg (1983); Chaetognatha: Casanova (1999); Ostracoda: Angel (Pers. Comm., World Ocean). SA: data for the South Atlantic. Total species considered: 8354.

(Fig. 1). These differences are coherent with our current perception of the degree of completeness of the corresponding species lists: proportions of undescribed taxa are much higher among the invertebrates than among the primates or the marine mammals.

Although marine zooplankton are neither conspicuous nor particularly "appealing", for most of them the highest rates in the description of new species occurred before and around the turn of the century, and have been dwindling down thereafter (Fig. 2). Data for the South Atlantic indicate that, on average, $78 \%$ of the species currently known to occur in these waters were described before 1925 (Boltovskoy, 1999a).

From the above discussions three important points emerge: (1) marine zooplanktonic species are comparatively few, (2) their description rates have been declining in the last decades, and (3) large proportions of them inhabit the three major oceans. In other words, as opposed to many other communities where, for example, a single tree may host hundreds of exclusive species of beetles (Wilson, 1999), marine zooplankton species are few and are present everywhere. These circumstances seem to indicate that our specific inventories of marine zooplankton are much closer to completion than those of most other communities (but see below).

Even considering that the efforts dedicated to faunisticdistributional studies have been declining steadily in the last decades (according to data compiled by the Aquatic Sciences and Fisheries Abstracts service, articles on the geographic distribution of marine organisms dropped from $3.9 \%$ of all publications included for 1985 , to $0.8 \%$ in 1993 ; cf. Boltovskoy, 1998; see also Gaston and May, 1992), we anticipate that more marine zooplanktonic species have already been described than are awaiting discovery. This is particularly valid for the predominantly pelagic, open-ocean groups, whereas for those with many neritic and/or planktobenthic forms the numbers of undescribed species are most probably larger (Angel, 1996).

\section{Blanks, gaps and future work}

In the preceding sections we attempted to show that specific inventories of marine zooplankton stand in a 


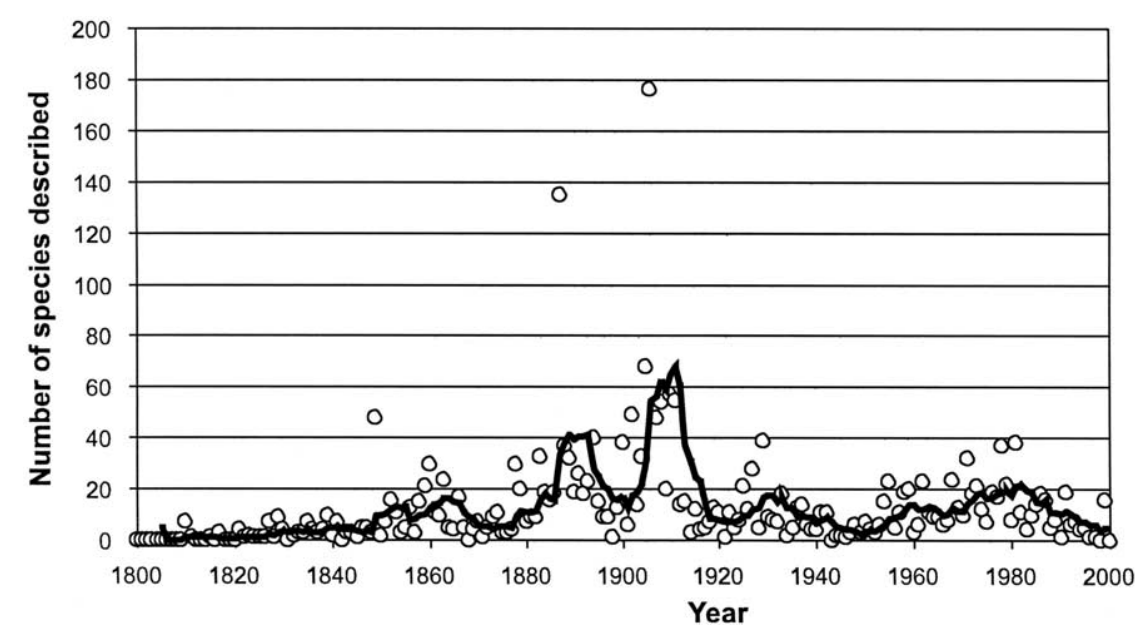

Fig. 2. Historical trend in the species description rates for 17 groups of zooplanktonic taxa (Acantharia, Amphipoda Chaetognatha Ciliophora, Copepoda Cubomedusae, Scyphozoa, Euphausiacea, planktonic Foraminifera, Heteropoda, Hydromedusae, Mysidacea, Ostracoda, Phaeodaria, planktonic Polychaeta, Siphonophorae, and Tintinnoinea) between 1800 and 2000. Species restricted to those recorded in the South Atlantic; data points (circles) and 7-point running mean (line). Sources are the same as for Fig. 1.

category of their own and cannot be compared with those of most other plants and animals. This situation stems from the peculiar constraints that govern evolution and speciation in marine zooplankton (e.g., Angel, 1996), suggesting that approaches toward the investigation of the biodiversity of these organisms may differ from those necessary for other plant and animal groups.

The first conclusion that emerges from these results is that, in the case of marine zooplankton, the search and description of new species is a costly investment with low potential yield because a large proportion of the existing species have already been named and described. While this seems true as far as traditional taxonomic methods are concerned, it may not apply to alternative approaches. For example, in the last decades molecular and ultrastructural studies have yielded very interesting results in the interpretation of long-standing evolutionary, taxonomic and distributional problems (e.g., Wood and Leatham, 1992; Bucklin, 1998; Amaral Zettler et al., 1998, 1999; Darling et al., 2000). This is a rather new field, and the contributions of molecular techniques to the taxonomy of marine plankton will most probably grow in the near future. However, we anticipate that new results will be of particular significance in reshaping current knowledge of phyletic relationships and species limits, but their impact on the size of the existing inventories will be limited. In other words, although the number of names erected is probably not too different from the number of existing species, proportions of names encompassing more than a single species, as well as groups of species (or cryptic species) under a single name, are still significant. While it is true that in many groups, particularly the lower ones, sibling species and species groups exist because they have few outward traits by which to separate them, it is our feeling that in many taxa synonyms by far outnumber the undescribed species (see below).
An indirect measure of the state of the taxonomy of the different zooplanktonic groups can be gained from the information conveyed by the corresponding binary names.

Some taxa, especially those with relatively few species, have reasonably stable taxonomic systems and binary names alone convey enough meaning to ensure a common standard throughout the world. Among these are the planktonic foraminifers, euphausiids, cladocerans, most pelagic tunicates, and a few others. With few exceptions species in these groups are reasonably well delimited and are known under the same name worldwide.

Several groups (e.g., copepods, amphipods, larval decapods, mysidaceans, cephalopods) are in an intermediate situation where the very high diversities (up to ca. 2000 described species for the Copepoda; see Table 1), associated with the presence of males and females, as well as numerous developmental stages, make the task of generating thorough inventories much more time-consuming. Our feeling is that these groups are less completely accounted for, but pending research benefits from the availability if a rather solid basement.

The third category also encompasses groups with large numbers of species, but whose taxonomic systems are in a serious state of disarray. Their systematics is far too sketchy for geographic comparisons to be meaningful, for which reason also distributional data are of poor quality. Good examples of the latter are the radiolarians (polycystines and pheodarians), the acantharians, and the tintinnids. The literature on these organisms is plagued with synonyms, to the point that in many cases binary names alone have little or no meaning. For example, although widely acknowledged as inadequate and artificial, the taxonomic system of Polycystine Radiolaria is still largely based on Haeckel's (1887) monumental monograph; over $50 \%$ of the $>3000$ species included in this work (2400 of them new species) are most probably synonyms derived from the misinterpre- 
tation of growth and dissolution stages (Boltovskoy, 1999b). The Phaeodaria and the Acantharia, also largely worked out by Haeckel (1887), have similar problems as well. The taxonomy of tintinnids is also plagued with synonyms, chiefly due to the widely used monographs of Kofoid and Campbell $(1929,1939)$, who indiscriminately raised to the rank of genus and species hundreds of tintinnids previously placed in lower categories. These authors described ca. 1000 tintinnid species, some 700 of which are most probably invalid (Alder, 1999).

A serious problem with the taxonomy of these protists is that their classification is entirely based on skeletal (radiolarians, acantharians), and lorical (tintinnids) features, rather than on the soft body. The fact that variations in skeletal/lorical morphology can generally be correlated with geographic distributional pattern supports the notion that these traits have both evolutionary and ecological value, but there is a growing body of evidence that cytological characters cannot be ignored if a natural classification system is sought (e.g., Hollande and Enjumet, 1960; Petrushevskaya et al., 1976; Laval-Peuto, 1981, 1983; LavalPeuto and Brownlee, 1986).

Acute synonymy problems are pervasive throughout the animal kingdom. Unfortunately, for the protists the prospects of improving this scenario in the foreseeable future are bleak. The chaotic state of the classification of benthic foraminifera was addressed by Boltovskoy (1965), stating that unless the erection of new species was handled more cautiously our efforts to build a useful body of knowledge were doomed. This warning had little effect: in 1978, Brolsma (1978) supplied four experienced specialists with four identical sets of benthic foraminifers containing 200 species. The four resulting identification lists shared only 10 generic names and only one (!) species.

Other potential gaps in our coverage of marine zooplanktonic inventories are (1) the meso- and bathypelagic fauna, and (2) the delicate, chiefly gelatinous plankton. Deep-sea plankton is not only considerably harder to sample, but also the sample size needed is much larger because densities of organisms drop exponentially with depth. Delicate, gelatinous plankton, in turn, do not preserve adequately in routine net plankton samples. Interestingly, non-conventional plankton sampling techniques, such as submersibles, have yielded a number of new gelatinous species from bathyal depths in recent years (e.g., Harbison, 1986). The unexplored diversity in these two categories, however, would not be expected to increase known zooplanktonic inventories to a degree nearly as large as those suggested for other communities (i.e., 10-fold or more, see above). This assumption is based on the fact that the gelatinous groups involved (chiefly scyphozoans, siphonophores and ctenophores) are not particularly rich in species (ca. 6\% of all zooplanktonic species, see Table 1). In addition, deep-sea plankton has much broader distributional ranges than the surface fauna, which makes them potentially more vulnerable to sampling programs. Indeed, wide-ranging forms represent only $11-12 \%$ of epipelagic plankton, but $38-42 \%$ of those living below 500-1000 m (Boltovskoy, 1999a).

Discovery and description of a (valid) species adds little to our knowledge if all we know is a name and the morphotype associated with it. As noticed by most workers when dealing with biodiversity-related issues, accounting for the species that inhabit our planet is more than giving each a name and a morphologic description. A name alone means close to nothing if we fail to understand key aspects of its biology, such as basic ecologic traits, reproduction and feeding habits, geographic, vertical and seasonal distribution patterns, etc. While this knowledge is scarce for but a handful species on earth, it is particularly inadequate for the marine zooplankton. There are entire groups whose distribution is known vaguely and in very general terms only. For example, there is not a single radiolarian, acantharian or tintinnid species for which the worldwide distribution in the plankton has been mapped with any degree of detail. Lack of sample coverage is further complicated by the absence of standardization of sampling methods and analytical protocols, and particularly the scarcity of international databases with taxonomic information (Angel, 1996). Distributional information is of particular importance because it conveys critical data necessary for survey programs aimed at monitoring the effects of natural and human-induced climatic changes.

\section{References}

Alder, V.A., 1999. Tintinnoinea. In: Boltovskoy, D. (Ed.), South Atlantic Zooplankton. Backhuys Publishers, Leiden, The Netherlands, pp. 321-384.

Amaral Zettler, L.A., Anderson, O.R., Caron, D.A., 1998. Insights on the diversity within a "species" of Thalassicolla (Spumellarida) based on 16S-like ribosomal RNA gene sequencing. J. Euk. Microbiol. 45, 488-496.

Amaral Zettler, L.A., Anderson, O.R., Caron, D.A., 1999. Towards a molecular phylogeny of colonial spumellarian radiolaria. Mar. Micropal. 36, 67-79.

Andreu, A., Braña, B.F., Galán, P., López-Jurado, L.F., Pérez-Mellado, V., Pleguezuelos, J.M., Salvador, Fauna Iberica. [http://www.fauna- iberica.mncn.csic.es/htmlfauna/faunibe/zoolist/ platyhelm/turbellaria.html].

Angel, M.V., 1999. Ostracoda. In: Boltovskoy, D. (Ed.), South Atlantic Zooplankton. Backhuys Publishers, Leiden, pp. 815-868.

Angel, M.V., 1996. Ocean diversity. In: Summerhayes, C.P., Thorpe, S.A. (Eds.), Oceanography. An Illustrated Guide. Wiley, New York, pp. 228-243.

Bacescu, M., 1988. Crustaceorum catalogus. Pars 7. Cumacea I (Fam. Archaeocumatidae, Lampropidae, Bodotriidae, Leuconidae). SPB Academic Publishers, The Hague, pp. 1-468.

Backus, R.H., 1986. Biogeographic boundaries in the open ocean. In: Pierrot-Bults, A.C., van der Spoel, S., Zahuranec, B.J., Johnson, R.K. (Eds.), Pelagic Biogeography. UNESCO Technical Paper in Marine Science, Vol. 49, pp. 9-13.

Bailey, R.G., 1996. Ecosystem Geography. Springer, New York, pp. 1-204.

Balech, E., Boltovskoy, A., In press. The Worldwide Species Key for the Genus Protoperidinium. ETI, Amsterdam. 
Bé, A.W.H., Tolderlund, D.S, 1971. Distribution and ecology of living planktonic Foraminifera in surface waters of the Atlantic and Indian Oceans. In: Funnel, B.M., Riedel, W.R. (Eds.), The Micropaleontology of Oceans. Cambridge University Press, London, UK, pp. $105-159$.

Beklemishev, K.V., 1969. Ekologiya i Biogeografiya Pelagiali. Nauka, Moskva, pp. 1-291.

Bernstein, R., Kling, S.A., Boltovskoy, Acantharia, D., 1999. South Atlantic Zooplankton. In: Boltovskoy, D. (Ed.). Backhuys Publishers, Leiden, pp. 75-147.

Boltovskoy, D., 1999b. Radiolaria polycystina. In: Boltovskoy, D. (Ed.), South Atlantic Zooplankton. Backhuys Publishers, Leiden, pp. 149-212.

Boltovskoy, D. (Ed.), 1999. South Atlantic Zooplankton. Backhuys Publishers, Leiden pp. ixvi + 1-1706.

Boltovskoy, D., 1998. Pelagic biogeography: background, gaps and trends. In: Pierrot-Bults, A.C., van del Spoel, S. (Eds.), Pelagic Biogeography ICoPB II, IOC Workshop Rep., 142, pp. 53-64.

Boltovskoy, D., 1999a. Diversidad y biogeografía del zooplancton del Atlántico Sur. An. Acad. Nacional Ciencias Exactas. Físicas y Naturales 51, 111-136.

Boltovskoy, D., Gibbons, M.J., Hutchings, L., Binet, D., 1999. General biological features of the South Atlantic. In: Boltovskoy, D. (Ed.), South Atlantic Zooplankton. Backhuys Publishers, Leiden, pp. $1-42$.

Boltovskoy, E., 1965. Twilight of foraminiferology. J. Paleontol. 39, 383-390.

Boltovskoy, E., 1981. Foraminifera. In: Boltovskoy, D. (Ed.), Atlas del Zooplancton del Atlántico Sudoccidental y Métodos de Trabajo con el Zooplancton Marino. Public Esp. Inst. Nac. Inv. Desarrollo Pesq., Mar del Plata, pp. 317-352.

Bouillon, J., 1999. Hydromedusae. In: Boltovskoy, D. (Ed.), South Atlantic Zooplankton. Backhuys Publishers, Leiden, pp. 385-466.

Bradford-Grieve, J.M., Markhaseva, E.L., Rocha, C.E.F., Abiahy, B., 1999. Copepoda. In: Boltovskoy, D. (Ed.), South Atlantic Zooplankton. Backhuys Publishers, Leiden, pp. 869-1098.

Briggs, J.C., 1996. Global Biogeography. Elsevier, Amsterdam, pp. $1-452$.

Brolsma, M.J., 1978. Benthic foraminifera. In: Zachariasse, W.J., Riedel, W.R., Sanfilippo, A., Schmidt, R.R., Brolsma, M.J., Schrader, H.J., Gersonde, R., Drooger, M.M., Broehman, P. (Eds.), Micropaleontological Counting Methods and Techniques - an Exercise on an Eight Meters Section of the Lower Pliocene of Capo Rossello, Italy. Utrecht Micropaleontol. Bull. 17, 1-265.

Bucklin, A., 1998. Molecular analysis of biogeographic patterns and processes: the copepod Nannocalanus minor in the N. Atlantic Ocean. In: Pierrot-Bults, A.C., van del Spoel, S. (Eds.), Pelagic Biogeography ICoPB II, IOC Workshop Report 142, 78-85.

Casanova, J.P., 1999. Chaetognatha. In: Boltovskoy, D. (Ed.), South Atlantic Zooplankton. Backhuys Publishers, Leiden, pp. $1353-1374$.

Darling, K.F., Wade, C.M., Stewart, I.A., Kroon, D., Dingle, R., Brown, A.J.L., 2000. Molecular evidence for genetic mixing of Arctic and Antarctic subpolar populations of planktonic foraminifers. Nature 405, 43-47.

Ekman, S., 1953. Zoogeography of the sea. Sidgwick \& Jackson, London, pp. 1-417.

Fernández-Alamo, M.A., Thuesen, E., 1999. Polychaeta. In: Boltovskoy, D. (Ed.), South Atlantic Zooplankton. Backhuys Publishers, Leiden, pp. 595-620.

Gaston, K.J., May, R.M., 1992. The taxonomy of taxonomists. Nature 356, 281-282.

Gibbons, M.J., Spiridonov, V.A., Tarling, G.A., 1999. Euphausiacea. In: Boltovskoy, D. (Ed.), South Atlantic Zooplankton. Backhuys Publishers, Leiden, pp. 1241-1280.
Groves, C.P., 1993. Order primates. In: Wilson, D.E., Reeder, D.M. (Eds.), Mammal Species of the World: a Taxonomic and Geographic Reference, Vol. 2. Smithsonian Institute Press, Washington, D.C, pp. 243-277.

Haeckel, E., 1887. Report on Radiolaria collected by H.M.S. Challenger during the years Rep. Sci. Res. Voyage H.M.S. Challenger 1873-76, $18,1-1803$.

Harbison, G.R., 1986. Toward a study of the biogeography of the pelagic ctenophores. In: Pierrot-Bults, A.C., van der Spoel, S., Zahuranec, B.J., Johnson, R.K. (Eds.), Pelagic Biogeography. UNESCO Technical Papers in Marine Science, Vol. 49, pp. 112-117.

Hemleben, C., Spindler, M., Anderson, O.R., 1989. Modern Planktonic Foraminifera. Springer, New York, pp. 1-363.

Hollande, A., Enjumet, M., 1960. Cytologie, évolution et systématique des Sphaeroidés (Radiolaires). Arch. Mus. Nat. Hist. Natur., Paris, Ser. 7, $1-134$.

Kemle von Mücke, S., Hemleben, C., 1999. Foraminifera. In: Boltovskoy, D. (Ed.), South Atlantic Zooplankton. Backhuys Publishers, Leiden, pp. 43-76.

Kling, S.A., Boltovskoy, D., 1999. Radiolaria Phaeodaria. In: Boltovskoy, D. (Ed.), South Atlantic Zooplankton. Backhuys Publishers, Leiden, pp. 213-264.

Kofoid, C.A., Campbell, A.S., 1929. A conspectus of the marine and freshwater Ciliata belonging to the suborder Tintinnoinea, with description of new species principally from the Agassiz Expedition to the Eastern Tropical Pacific 1904-1905. Univ. California Pub. Zool. 34, 1-403.

Kofoid, C.A., Campbell, A.S., 1939. Reports on the scientific results of the expedition to the Eastern Tropical Pacific. The Ciliata: the Tintinnoinea. Bull. Mus. Compar. Zool. Harvard Coll. 34, 1-473.

Komarek, J., Fott, B., 1983. Chlorophyceae (Grunalgen). Ordnung: chlorococcales. In: Huber-Pestalozzi, H. (Ed.), Das Plankton des Susswassers, Systematik und Biologie, Teil 7, Halfte 1. E. Schweizerbartsche Verlagsbchhandlung, Stuttgart, pp. 1-1044.

Laval-Peuto, M., 1981. Construction of the lorica in ciliata tintinnina. In vivo study of Favella ehrenbergii: variability of the phenotypes during the cycle, biology, statistics, biometry. Protistologica 17, 249-272.

Laval-Peuto, M., 1983. Sexual reproduction in Favella ehrenbergii (Ciliophora, Tintinnina). Taxonomical implications. Protistologica 29, 503-512.

Laval-Peuto, M., Brownlee, D.C., 1986. Identification and systematics of the Tintinnina (Ciliophora): evaluation and suggestions for improvement. Ann. Inst. Océanogr., Paris 62, 69-84.

Longhurst, A., 1998. Ecological geography of the sea. Academic Press, San Diego, pp. 1-398.

McGowan, J.A., 1974. The nature of oceanic ecosystems. In: The biology of the Oceanic Pacific (Ed.). Oregon State University Press, pp. 9-28.

McGowan, J.A., Walker, P.W., 1993. Pelagic diversity patterns. In: Ricklefs, R.E., Schluter, D. (Eds.), Species Diversity in Ecological Communities. Historial and Geographic Perspectives. University of Chicago Press, Chicago, pp. 203-214.

Mianzan, H.W., Cornelius, P., 1999. Cubomedisae and Scyphomedusae. In: Boltovskoy, D. (Ed.), South Atlantic Zooplankton. Backhuys Publishers, Leiden, pp. 513-560.

Mordukhai-Boltovskoi, F.D. (Ed.), 1972. Opredelitel fauny Chernogo i Azovskogo Morei. Tom 3. Svobodnozhyvuschiye bezpozvonochnye. Naukova Dumka, Kiev, pp. 1-340.

Mordukhai-Boltovskoi, F.D. (Ed.), 1969. Opredelitel fauny Chernogo i Azovskogo Morei. Tom 2. Svobodnozhyvuschiye bezpozvonochnye. Rakoobraznye. Naukova Dumka, Kiev, pp. 1-536.

Murano, M., 1999. Mysidacea. In: Boltovskoy, D. (Ed.), South Atlantic Zooplankton. Backhuys Publishers, Leiden, pp. 1099-1140.

Noreña, C., 1999. Fauna Iberica [http://www.fauna-iberica.mncn.csic.es/ htmlfauna/faunibe/zoolist/platyhelm/turbellaria.html]. 
Northridge, S.P., 1984. World review of interactions between marine mammals and fisheries. FAO Fish. Technical Paper 250, pp. 1-190.

Petrushevskaya, M.G., Cachon, J., Cachon, M., 1976. Comparativemorphological study of radiolarians: foundations of new taxonomy. Zool. Zhurnal 55, 485-496.

Petz, W., 1999. Ciliophora. In: Boltovskoy, D. (Ed.), South Atlantic Zooplankton. Backhuys Publishers, Leiden, pp. 265-320.

Pierrot-Bults, A.C., van del Spoel, S., 1979. Speciation in macrozooplankton. In: van del Spoel, S., Pierrot-Bults, A.C. (Eds.), Zoogeography and Diversity of Plankton. Bunge, Utrecht, pp. 144-167.

Pugh, P., 1999. Siphonophorae. In: Boltovskoy, D. (Ed.), South Atlantic Zooplankton. Backhuys Publishers, Leiden, pp. 467-512.

Richter, G., Seapy, R.R., 1999. Heteropoda. In: Boltovskoy, D. (Ed.), South Atlantic Zooplankton. Backhuys Publishers, Leiden, pp. 621-648.

Saiz Salinas, J.I., 1993. Sipuncula. In: Ramos, M.A. (Ed.), Fauna Ibérica, Vol. 4. Mus. Nac. Cienc. Natur., CSIC, Madrid, pp. 1-200.

Sieg, J., 1983. Crustaceorum catalogus. Pars 6. Tanaidacea. SPB Academic Publishers, The Hague, pp. 1-552.
Sournia, A., Chretiennot-Dinet, M.J., Ricard, M., 1991. Marine phytoplankton: how many species in the world ocean? J. Plankton Res. 13, 1093-1099.

Spoel, S. van der, Dadon, J.R., 1999. Pteropoda. In: Boltovskoy, D. (Ed.), South Atlantic Zooplankton. Backhuys Publishers, Leiden, pp. 649-706.

Starmach, K., 1983. Flora Slodkowodna Polski. Tom 3. Euglenophyta. Panstwowe Wydawnictwo Naukowe, Warszawa, pp. 1-594.

Vinogradov, G., 1999. Amphipoda. In: Boltovskoy, D. (Ed.), South Atlantic Zooplankton. Backhuys Publishers, Leiden, pp. 1141-1240.

Wilson, E.O., 1999. The Diversity of Life. Norton, New York, USA, pp. $1-424$.

Wood, A.M., Leatham, T., 1992. The species concept in phytoplankton ecology. J. Phycol. 28, 723-729.

Zenkevitch, L.A., 1960. Spetzialnaya kolichestvennaya kharakteristika glubokovodnoi zhizni v okeane. Izvestiya Akad. Nauk SSSR, Ser. Geograf. 2, 10-16. 